\title{
Financial-Economic Crisis and Hollywood's Social Transformation Operations by Horror Movies
}

\author{
Asst. Prof. Dr. Ramazan Kurtoğlu (Istanbul Aydın University, Turkey)
}

\begin{abstract}
The fastest change and transition in the human history is neoliberal capitalism's 30 year global free market politics project which affects every part of the world with 1978 Washington Consensus. According to John Gray who is a well known academician and an intellectual of the new right-wing, neoliberalism is an apocalyptic secular religion which is based on pagan and Christian values and its ultimate goal is post-apocalyptic heaven in the real world. The best marketing expert of this heaven is, Hollywood based American cinema industry in crisis as well as in regular times. In this study, the effects of the horror movies to the subconscious under economical crises period will be analyzed.
\end{abstract}

\section{Introduction: Transformation for Global Open Market}

The theoreticians of the New World Order use the concepts of center and environment to deal with international issues. These concepts mean that Hollywood spreads from center to environment with its transnational industry-finance complexities in the sense of economical-cultural-political globalization, and that it invades local communities with all their possessions. Over 2.5 billion of global population is deprived of basic health services. Every year, 11 million children under the age of five, in other words 30 thousand children per day die because of preventable reasons.

Throughout the human history, especially since the end of 1970s a new ground was broken. Around seven billion people experienced an unhealthy and fast change and transformation in mass. The most important engine of this change and transformation is Hollywood, the center of American film industry. The cinema films and TV series produced under the control of this center put into practice the projects that are aimed to affect the children and adults to create prototypes, which neoliberalism desires, through incredible subliminal affects. The cartoons (such as The Lion King and Mermaid) made children reach early puberty, sent sexual senses to their subconscious and created masses who possess and consume but are never content with what they have. As the publisher of Frankfurter Allgemaine Zeitung (FAZ), which is the most influential right wing newspaper of Germany, Frank Schirrmacher, who is also an early neoconservative, states in his books titled Ego-Das Spiel and Des Lebens that an egomaniac humanity has been formed.

In this process, the communication methods which persuade by entertainment rather than by force are/has been used. As a general tactic, some methods such as fear, punishment, discouragement and decent threats against individuals are used to influence individuals for attitudes and behaviors that are intended. One of the most significant medium is horror movies.

"The element of fear is one of the main elements that are used for these subconscious messages in addition to its appearance. The reaction of brain against death and fear are quite different from the ones against other things. Fear factors often take part in the hidden images used in subconscious messages. This sometimes appears through inscription, sometimes weird and fearful facial expressions, skulls and symbols."

The military doctrine that USA used in Iraq's invasion is named weirdly Bible-based and proper to the teopolitical Evangelist-Christian discourses as shock and awe: "Shock and awe are actions that create fears, dangers, and destruction that are incomprehensible to the people at large, specific elements/sectors of the threat society, or the leadership. Nature in the form of tornadoes, hurricanes, earthquakes, floods, uncontrolled fires, famine, and disease can engender Shock and Awe."

The keystones of US government's policy are hidden in the roots of the founder legends which the founding elites/ancestors impose upon American identity. These are a-Wild West, b-Frontier, c-City Upon the Hill and dPredestination and they all determine the strategic frame of US' domestic and international political-financialmilitary relations. Four of these elements mentioned above originate from Kabala and The Bible.

American journalist David L. Robb claims in his book Operation Hollywood that Pentagon censors war movies, and through psychological operation elements, Hollywood productions misdirect both American people and humanity. Stephen Kinzer, one of the former reporters of New York Times, states that the US takes place in global operations through three stages and the first of these stages is the demand from the US centered transnational companies. Also it is obvious that these companies are in relationship both directly and through Wall Street with big producer companies in Hollywood. It is more important to obtain public's subconscious than land.

The elements that build the collective unconsciousness are called archetypes or models. Jung names them as dominants, mythological or primitive figures, as well. An archetype is an untaught tendency that is gained through a certain experience. Archetypes don't have a peculiar form, rather it undertakes an ordering principle 
role on the things we see or do. In other words, an archetype is like a black hole in space; the presence of which we can only tell from the object or light it inhales. The most commonly used two archetypes in unconscious messages are "birth" and "death" archetypes. The influence of these on people is high and they do not differ from one to another. The unconscious identifies the events that are related to our vital experiences which lead these two archetypes to exist and occur with these archetypes. Although fear and awe are shown as different factors in some sources, as the working principle of unconscious and brain scanning experiments clearly indicate, they are actually directly related with the death archetypes.

Some experts who evaluate and interpret the indications of restlessness and traumas that the society has, categorize such fantastic cinema genres as horror or science fiction as crisis cinema or crisis movies. "It can be said from the choice of category that cinema is in direct relationship with social changes. If the Hollywood cinema is considered, it is clear that it has parallelism with the position and ideology of US government, which is the shaper of this relationship.... The influence of economic crisis lies behind the Hollywood horror cinema, and the increase in the production of horror films cause any resistance that this crisis would build to be quelled without violence. ... the scene, subject, fiction and scenario of Hollywood horror cinema vary."

\section{Crisis - Hollywood Horror Cinema and Subconscious Operations}

The Hollywood productions, part of the definition of media are not aimed only at entertainment. There definitely must be an overlap or consolidation between big Hollywood film companies and Wall Street banks, financial companies and bankers. "... In addition to its other functions, media also serves in charge of the profits of the strong communal groups who both control and finance it and it makes propaganda for them. .. It does not achieve this by brutal force; rather, it achieves it through the choice of right personnel who think in the favorable way, initiatives of editors and journalists which match the policy of the corporation, and their internalization of the criteria of newsworthiness."

Dr. Dimitry Polyvyanny, one of the professors of Ivanovo University in Russia, who came to Istanbul with Yeditepe University's invitation; is specifically known for his studies about the relativity of reality. The thesis he advocates is that: "The communities of various countries are horribly mistaken by the publication of some certain programs which do not exist in cinema and TV channels, especially in media." He names this deep diversion as CNN effect starting from the French thinker Jean Baudrillard's views.

According to the scientific researches, as the most important item of media, TV prevents the limbic system of children which is also called emotional brain from improving and thus, the brain becomes incapable of producing its own images, staying under the influence of the images only on TV and becoming thinking only within the limits of what TV presents. Another significance of limbic system on child development is that the development of limbic system in the brain, also, simultaneously improves the children's sense of conscience, which means there is a directly proportional development. If the limbic system in the brain fails to improve enough, it leads to a community of terminator derivative which does not legitimize the concept of conscience.

Another important media organ is computers and doubtlessly computer games. A research in America, which is the biggest producer of computer games, proves that these kinds of games make the children not only lazy, but also profane and aggressive. "Computer games are rapidly becoming a big part of communities, and the researches prove that the cultural, economic and social influence of this culture of game on societies are getting more and more dense."

Whereas the world is getting smaller and smaller with the leadership of transnational companies with 1978 Washington Agreement, everything from culture to gender is becoming marketable commodities. The most influential weapon of this process is the propaganda oriented to the unconscious of children, youth, women and men, in short, every aspect of the society. Thus, "the expensive movies, the film industry under the control of global bankers, global productions aimed specifically at children and youth, games and other products ... They all look basically innocent... But are they really innocent?"

"The propaganda model explains the broad sweep of the mainstream media's behavior and performance by their corporate character and integration into the political economy of the dominant economic system. For this reason, we focused heavily on the rise in scale of media enterprise, the media's gradual centralization and concentration, the growth of media conglomerates that control many different kinds of media (motion picture studios, TV networks, cable channels, magazines, and book publishing houses) and the spread of the media across borders in a globalization process. We also noted the gradual displacement of family control by professional managers serving a wider array of owners and more closely subject to market discipline." In short this is the situation of US media in the sense of propaganda model. So, how many people control this enormous mechanism?

"Of the nine giants that now dominate the media universe, all but General Electric have extensively conglomerated within the media, and are important in both producing content and distributing it. Four of them Disney, AOL Time Warner, Viacom, and News Corporation-produce movies, books, magazines, newspapers, TV programs, music, videos, toys, and theme parks, among other things; and they have extensive distribution 
facilities via broadcasting and cable ownership, retail stores, and movie-theater chains. They also provide news and occasional investigative reports and documentaries that address political issues, but the leaders of these popcultural behemoths are mainly interested in entertainment, which produces large audience with show like ABC TV's Who Wants to Be a Millionaire and CBS-TV'S Survivor, or with movies like Disney's Lion King that also make possible the cross-selling "synergies" that are a focal point of their attention and resources."

Significant branches of media such as film and books have had extensive global markets for years; but it took twenty years for the national media systems and a global media system having distinctive influences on culture and politics to form.

In other words; the rapid growth of the New World Order which started with the 1978 Washington Agreement, global open market, correlatively global advertising and film industry; advance communication technologies which make the control over transnational operations easier; and the reinforcement of neoliberal ideology with the control of the nation-states over government policies all accelerated the process. "The United States and other Western governments have pressed the interest of their home-country firms eager to expand abroad, and the International Monetary Fund (IMF) and World Bank have done the same, striving with considerable success to enlarge transnational corporate access to media markets across the globe. Neoliberal ideology has provided the intellectual rationale for policies that have opened up the ownership of broadcasting stations and cable and satellite systems to private transnational investors."

If we look at today's communities, we can see that a neurotic structure is dominant. The seemingly liberal, democratically discoursed governments of neoliberalism seem to be democratic. "Because, their desires and motives that prove the opposite exist somewhere undiscoverable in their unconscious. There is not an exterior, concrete oppression which can make the society's unconscious discoverable or mischief behind the neoliberal power. In this modern society, thus, which ignores the invisible and is used to visuality; there is very little consciousness that moves behind the screen and tries to resist negations seeing the broader social frame."

The psychological improvement of the collective depression that occurs as a result of economic crisis forms with the corporations that take place in cultural industry. The reason is that cultural activities are, in some way or another, the ways people express their existence and share it. And it is quite important where the messages given lead the society to. For this reason, the most important characteristic of cultural industry corporations is that they control masses through leisure cultural activities and influence their ways of thinking. Our unconscious is related to our taught behaviors and survival experiences. Especially in the editing of Hollywood production films and their scenarios, certain scenes related to the desired mood in the individuals exist. The scenario and technique of the film creates a certain mood not only on the unconscious, but also the conscious level. This mood, which leads to pleasure sensations such as love and sex that create fear and anxiety like violence and death, prepares a mental base for the actual message beforehand. This forms a basis and mood for unconscious messages which appear towards the end of the movies more, and increases its affectivity.

It is important for the messages of the Hollywood movies to be influential to prompt the masses who want to escape from reality by fantasizing its ideology, and to simplify the message to a language which can be understood and shared by everyone by stereotyping individuals. "Because Hollywood can affectively express its message by keeping its simplicity to keep the society's pulse and choosing the subjects in accordance with everyone's interests. The control is gained with the usage of neoliberal capitalism as a tool of oppression upon societies' cultural dynamics with a sense of fear, and Hollywood makes this fear expand to the entire globe with the same message it transmits the entire world."

The prototype individual model of neoliberalism is an individual which belongs to "a contemporary society whose values are based on a competitor, acquisitionist and intense alienation which relies on a fetishized sight rather than substance for its own existence."

The mass media, especially Hollywood serves as a system which transmits the messages and symbols to common people. Entertaining, amusing, informing, setting the values, beliefs and behavior codes which ties individuals to the societies in conscious and unconscious are just a few of its functions. In a world in which prosperity and capital are in certain hands and which obtains important beneficial conflicts; performing this role requires a systematic propaganda.

In many countries which keeps hold of power balances in state bureaucracy, the monopolist control over media which is mostly completed by censorship clearly exhibits that media serves a certain group elites. In the places in which media is in private hands and there is no official censorship, it is more difficult to see a functioning propaganda system. ... Propaganda model focuses upon the inequality of wealth and power and its multidimensional influence on mass media's benefits and choices.

Hollywood centered American film industry, which is a part of the media sector, has achieved a significant success in its aim of creating a global prototype with its operations directed to visual and unconscious level. The most important point here is that the personality has to fit in to certain stereotypes and approaches created by modernity, and thus it departs from selfness/naturalness by alienation. This alienation leads to the rush of the modern individual to find self and his/her escape from the reality of the world s/he belongs to. If we analyze this 
situation from the aspect of cinema, especially Hollywood cinema, we can see that neoliberal capitalism forms a horror cinema, a simulation of real fear as a reminder to ensure the other intimidation mechanisms' continuity, and it claims that it does it with the purpose of entertainment. This simulation it forms becomes one of the most important shelters of the modern individual who wants to escape from reality. The fact that horror cinema, especially Hollywood productions is a mechanism, a propaganda tool which works for the intimidation policies is easily hidden behind the charming cover which is embellished with visual effects. Here, discourse and context are very important. The entertainment sector, which seems to be the least harmful element of the cultural industry, uses Hollywood cinema's power of exhibition, skill of expressing directly to transform and pacify masses. The Hollywood production horror films threaten the mass who watch them to avoid from the impacts of economic/financial crisis with a scarier, superior secret power. When the spectacles are threatened with the existence of this power, they think that they are only entertaining, it is only a movie, rather than they are under threat. Meanwhile, the messages that they want to transport into each spectacle's unconscious are successively conveyed. Fear narrows the unpredictability limits of both the individual's and masses'. Hereby the resistance of the ones who are to resist against inequality, injustice, inequity is weakened both spiritually and materially because the sense of anxiety that the horror movies create has weakened the strong beliefs of hearts and the courage of the individuals. In this respect, the most alarming side of this anxiety series which is placed in human unconscious by Hollywood production horror movies is that the things people know and see in daily life suddenly become different and unfamiliar. Thanks to this sense of alienation and unfamiliarity another secret is added to the regular things and this situation is the subliminal influence which forms the threat itself.

According to the researches not only the voting rate of the liberal parties increased after the economic crisis, but the number and popularity of horror movies also increased. In many Hollywood productions, the messages such as loyalty to authority, salvation, post-apocalyptic heaven to protect people from economic crisis or anything that pose danger are transmitted with gradually increasing dose. Actually economic/financial crisis has no difference from a horror movie in terms of the anxiety it creates in individuals and masses. The picture after the crisis has become literally threat at home. Now we are together with a zombie from the horror movies which we carry in our pockets, and which exploits our existence and family. We are face to face with this monster which sucks our blood like a vampire. Such influences that lead to anxiety series and deepen them cause depression in individuals. And depression led to the uncommon extension of usage of Prozac or other antidepressants. Hence, according to the Republic of Turkey Ministry of Health and Turkish Doctors' Union's reports, in 2012, 37 million boxes of anti-depressant have been used in Turkey.

The statistical data show that there is a clear increase in the Hollywood production horror films after the years of economic crisis, which strengthens the claim that economic crisis and Hollywood films are in relation. famous Cabbalist pop singer Madonna says in her song named Hollywood: "I lost my memory in Hollywood / I've had a million visions, bad and good/There's something in the air in Hollywood/I tried to leave it but I never could" Another celebrity Marilyn Monroe also says that "Hollywood is a place which gives two million dollars for your kiss while two dollars for your soul."

Screen Reality: this significant concept can be assumed as a virtual reality which cannot be separated from object reality like in Baudrillard's Simulacra, and can replace it. The sensation we get with our five senses from the outer world leaves its place to the virtual reality we get from screens every single day. Think about the time we waste in front of computers, cell phones, monitors! How much did the time we spend in front of screens increase compared to five or ten years ago?

The beginning of disaster films which is a new genre launched especially in 1970s coincides with the period that WASPs and Jews began unfreezing. Now, Hollywood cinema has started elaborately to handle the theories about the end of the world. With the period of 1968, the annual rate of horror film production has doubled in Hollywood; and after the year 2000 this rate has tripled. While in 1970 the number of horror films directed in Hollywood is only 13, in 1980 it was 40, in 1990 it was 72, in 2000 it was 71, in 2005 it was 181 and in 2009 it was 745. What was unnatural and inhumane after the horror films and economic crisis process is that they manipulate people's worries and exploit their emotions by playing with their unconscious through cinema which is one of the mass media tools used by the global free market ideology to make the sufferings forgotten. The result of this manipulation is the silence of the masses. The horror films that feed neurotic fear also trigger learned helplessness. In other words the depression nourished by learned helplessness is a daily mood nourished by neurotic fear because neurotic fear occurs when one suffers the consequences of what they do and cannot change them, and it leads to a lack of desire for struggle against life by breaking individuals' resistance dynamics. Learned helplessness, on the other hand, occurs when the depressed individual learns the fact that despite their struggles nothing will change, and they can never control anything.

In the Hollywood product horror movies, there is a lot of emphasis on individual remorse. This kind of emphasis is the deep message in the subtext which leads us to simplify the reasons and results of the economic/financial crisis to individual level, and to look for the reasons of all the social issues in the individuals. Actually this is what the elites, who build the neoliberal apocalyptic utopia, want. It is not the system. Some people getting out of this system have caused this disaster. A scapegoat is to be created and victimized. The 
failure of humanity and honor caused by the economic crisis with the loss of such elements as employment, money or life insurance becomes an exemplary fact which results from the fact that characters in horror films are shown to be defecated from mind and reduced to instincts, with the disparagement of the uncivilized human life who has been purified from social values. While Hollywood's traditional scenarios are always on similar themes, it uses certain elements for certain missions. In Hollywood, every message has an aim. None of the films has only the aim of entertainment.

Some of the science fiction horror and horror films, which are, also, the source of inspiration are The Excorsit (1973), Armageddon (1998), Blade Runner or Do Androids Dream Electric Sheep (1982), Minority Report (2002) and The Ruins (2008). Of course there are hundreds of others, as well because Hollywood owns a quite generous production list on this issue. After all, the claim that Hollywood cinema is the biggest weapon of the global free market secular religion of neoliberal capitalism's policy to make world a "World Company" should not be assumed as an exaggeration.

The fact that subliminal messages have more influence in a shorter course is related with the perceptual process. Throughout the perception, the reaction one gives to the perceptions does not include only that exact moment (during which the message is transmitted). It is also in relation with past experiences and other data in one's memory. The perceptual process is oriented at the whole on the conscious level, and it can apprehend the details only in the subconscious level. The unconscious message is organized in detailed pieces so as not to be realized by conscious level. Hollywood claims with the messages transmitted through the horror movies following the economic crisis that there is a crisis; an enormous nightmare about those who get hokey against the injustice after the economic crisis and those who get out of herd acceptance. Cinema uses entertainment rather than force as a compromise and socialization strategy. This situation, the distance of entertainment from strictures covers up a lot of issues; makes the cinema-film industry one of the most dangerous mass conversion tool. The fact that the horror elements of culture are entertaining, which is legitimized under the roof of entertainment concept, is based on an invisible strategic policy which works more influentially than other psychological operation corporations. At this point a global change occurs, especially Hollywood cinema becomes superior then other psychological war corporations at influencing human unconscious as it changes people's living rhythms and rituals in accordance with the system's desire by organizing people's spare times. A movie, as an experience, narcotizes people's conscious, and restrain them to their unconscious instincts and primary intuitions. The person besieged with huge display and loud sounds in the darkness experiences more than only watching a movie in a cinema hall because a movie lets neither time nor space for the spectacle to think and resist as it evokes both eyes and ears.

Pagan, the global free market utopia of neoliberalism, legitimizes secular political ideology, which is fed by judeo-Christian beliefs using the best film industry, and creates newer elements of anxiety by narcotizing mass mind. Now, there is no more rational capitalism. The invisible hand of capitalism, also, is the globalized, elitist and monopolist financial capital which orders the world by growing enormously. The human logic to criticize and question the system and corporations is narcotized by Hollywood cinema. Although in the Quran, the sacred book of Islam, there are 700 verses meaning "Don't you ask your minds?", it is unfortunately obvious that humanity does not have a self control. So, it should not be assumed as an exaggeration that the biggest manipulation element is the subliminal operations practiced by Hollywood products.

\section{Conclusion: Awakening Minds to Recover from Instability}

"Today elected governments run the majority of states in the world. The majority of CEOs of the biggest banks and international corporations are those who are the best and the brightest - the ones who have graduated with merit from the world's leading universities. Today citizens are better educated, better informed, their rights are better protected and they are more empowered to resist the authority of the state than ever before. Both the political and business elites are more diverse than ever in their ethnic, gender, race and class makeup, while being better connected and much more homogeneous with regard to their cultural tastes and ideas about governance. But neither the rise of democracy, nor the rise of meritocrats have eased publics' growing anxiety that 'markets aren't working the way they are supposed to, for they are neither efficient, nor stable; that the political system hasn't corrected the market failures; and that the economic and political systems are fundamentally unfair.' ... So why modern elites have no legitimacy and capacity to govern?" One of the most important corporations of these elites is the Bilderberg Conferences. Stephen Lendman writes: "The elites of Bilderberg is planning to set up a world which is not suitable to live in and they may destruct the whole world within this process in the final analysis. It is difficult to conceive a more evil-minded power than Bilderberg. The American members of Bilderberg Conference reveals the extent of things that this power may bring about with the worst example."

The humanity is brought face to face with a war, in a sense, more than seven billion people put on a target board has been destabilized with secret methods. In other words this is what the neoliberal global free market myth, which is the financialized version of capitalism has been doing for the last 30 years. To destabilize means 
to call the financial operation masters for duty to destroy the social and economic structures of countries. The economic war is a kind of a dirty war which the elite fathers controlling the financial environment of the globe love. Although they are no less fatal than the atomic bombs or bombarded Nagasaki, Dresden or Baghdad; they are more easily sold to today's humanity who are narcotized by Hollywood films.

\section{References}

- Gardner, Gary, "The Challenge for Johannesburg: Creating a More Secure World”, Worldwatch Institue, State of the World, 2002.

- Darıcı, Sefer, "Subliminal İşgal - Bilinçaltımızı Ele Geçiren Mesajlar”, Destek Yayınları, İstanbul 2012.

- Ullman, Harlan K. and Wade, James P., "Shock and Awe: Achieving Rapid Dominance", NDU Press Books, Washington D.C, 1996.

- Valantin, Jean-Michel, “Küresel Stratejinin Üç Aktörü.Hollywood Pentagon ve Washington”, Türkçesi: Ömer Faruk Turan, Babıali Kültür Yayıncılığı, İstanbul 2006. (Original Name: Hollywood, le Pentagone et Washington: Les trois acteurs d'une strategie globale)

- Kurt, R. Kağan, “Türkler ve Mesihusa”, Truva Yayınları, İstanbul 2007.

- Robb, David L., "Hollywood Operasyonları”, Türkçesi: Sinan Okan, Güncel Yayınlar, İstanbul 2005. (Original Name: Operation Hollywood: How the Pentagon Shapes and Censors the Movies)

- Kinzer, Stephen ile Yapılan Mülakat, 21 Nisan 2006, www.democracy.org.

- Ryan, Michael ve Kellner, Douglas, "Politik Kamera", Türkçesi: Elif Özsayar, Ayrıntı Yayınları, İstanbul 1997. (Original Name: Camera Politica: The Politics and Ideology of Contemporary Hollywood Film)

- Balseven, Ed. Hale ve Ercan, Fuat “Kriz ve Türkiye - Aşınan Teoriler” İçinde Sevde Yazıcı, "Kriz ve Korku: Sinema Üzerinden Krizin Sinemasal Algısı", Phoenix Yayınları, Ankara 2013.

- Herman, Edward S. ve Chomsky, Noam "Rızanın İmalatı - Kitle Medyasının Ekonomi Politiği”, Türkçesi: Ender Abadoğlu, bgst Yayınları, İstanbul 2012. (Original Name: Manufacturing Consent: The Political Economy of the Mass Media)

- Polyvyanny, Dmitry, Leyla Tavşanoğlu Mülakatı, Cumhuriyet Gazetesi, 2 Aralık 2012.

- Ersoy, Ruhi, “Çocuk, Şiddet, TV, Bilgisayar Oyunları ve Katliamlar”, Ortadoğu Gazetesi, 19 Aralık 2012.

- NTVMSNBC, "Bilgisayar Oyunları Saldırgan Yapıyor”, 24 Kasım 2004.

- Kurt, Ömür, "Küçük Adamlara Büyük Oyunlar”, Pozitif Yayınları, İstanbul 2013.

- Herman, Edward S. ve McChesney, Robert, "The Global Media”, Cassell, Londra, 1997.

- Oskay, Ünsal, "Çağdaş Fantazya", Der Yayınları, İstanbul 2000, s.65.

- Carey, Alex, "Reshaping the Truth: Pragmatists and Propagandists in America", Meanjin Quarterly, Cilt 35, 1976, No: 4.

- Kurtoğlu, Ramazan, “Evanjelizm - Hollywood ve Kabala'nın 13. Havarisi”, Sinemis Yayınları, Ankara 2012.

- Seçkin, Levent, “Çok Önemli Bir Kavram Ekran Gerçekliği”, Bilim ve Ütopya Dergisi, Aralık 2011, Say1:210.

- Gray, John, “Kara Ayin-Apokaliptik Din ve Ütopyanın Ölümü”, Türkçesi: Bahar Tırnakçı, YKY, İstanbul 2013. (Original Name: Black Mass:Apocalyptic Religion and the Death of Utopia)

- Foster, John Bellamy, “Kapitalizmin Malileşmesi ve Kriz”, Kalkedon Yayınları, Türkçesi: Çiğdem Çidaml, İstanbul 2008. (Original Name: The Financialization of Capitalism and the Crisis)

- Krastev, Ivan, "Niçin Modern Elitlerin Meşruiyeti ve Yönetme Kapasitesi Kalmadı", Turquie Diplomatique, 15 Temmuz-15 Ağustos 2013, Sayı: 54. (Original Name: Why Modern Elites Have No Legitimacy and Capacity to Govern)

- Lendman, Stephen, “Küreselleşmenin Yüce Rahipleri: Bilderberg Konferans Buluşmaları”, Turquie Diplomatique, Temmuz 2013, Say1: 54. (Original Name: The High Priests of Globalization : Bilderberg Conference Convenes ) 